\title{
State Approaches to Therapeutic Interchange in Community Pharmacy Settings: Legislative and Regulatory Authority
}

\author{
Thomas Vanderholm, PharmD; Donald Klepser, PhD, MBA; and Alex J. Adams, PharmD, MPH
}

\begin{abstract}
SUMMARY
Therapeutic interchange is the act of switching a prescribed drug for another drug in the same therapeutic class that is believed to be therapeutically similar but may be chemically different. Therapeutic interchange is different from generic substitution in that it does not occur between therapeutically equivalent products; instead, products are substituted for those that are likely to have a substantially equivalent therapeutic effect generally at a lower cost. Therapeutic interchange is common in institutional settings across the United States but rarely occurs in community pharmacy settings without a pharmacist first contacting the original prescriber and requesting a new prescription in order to facilitate a change.

As of 2018, Arkansas, Idaho, and Kentucky have passed laws to enable therapeutic interchange in community pharmacy settings. In general, these laws require the original prescriber to opt-in to allow therapeutic interchange, and the pharmacist generally must leverage the formulary of the patient's health plan to guide decision making within the same therapeutic class. These 3 states require that the pharmacist notify the original prescriber of any interchange in order to ensure a complete and accurate medication record. When appropriately structured, state laws enabling therapeutic interchange in community pharmacy settings allow pharmacists to use their medication expertise to save valuable time and enhance patient care while reducing health care costs.
\end{abstract}

J Manag Care Spec Pharm. 2018;24(12):1260-63

Copyright $\odot 2018$, Academy of Managed Care Pharmacy. All rights reserved.

$\mathrm{R}$ ising drug prices are a significant driver of total health care costs, with an $8 \%$ drug price increase expected in 2018. ${ }^{1}$ One tool to combat rising drug prices is therapeutic interchange, the act of switching a prescribed drug for another drug in the same therapeutic class that is believed to be therapeutically similar but may be chemically different. Therapeutic interchange is differentiated from generic substitution in that it does not occur between therapeutically equivalent products; instead, products are substituted for those that are likely to have a substantially equivalent therapeutic effect, generally at a lower cost. ${ }^{2}$

One study has found that in statin medications alone, there was a $10 \%$ cost saving in a 2 -year period due to therapeutic interchange. ${ }^{3}$ A second study found that therapeutic interchange saved a managed care organization a mean of $\$ 20.31$ per prescription filled and saved patients a mean of $\$ 14.76$ per prescription filled. ${ }^{4}$ Johansen and Richardson (2016) estimated potential savings of therapeutic interchange and projected savings of $\$ 73$ billion in excess branded drug overuse. ${ }^{5}$
Therapeutic interchange has been a common practice in institutional settings and has been in use at more than $80 \%$ of hospitals since 2002.6.7 In these settings, formularies are developed by an interdisciplinary pharmacy and therapeutics committee where health care practitioners decide which medications are appropriate for interchange. Institutional pharmacists can freely interchange products in accordance with the formulary.

Less common is the practice of therapeutic interchange in community pharmacy settings. Currently, a pharmacist must contact the original prescriber and request a new prescription in order to facilitate a change, which results in delayed patient care and imposes an administrative burden on both parties ${ }^{8-10}$ Community pharmacies do not have closed formularies nor formulary committees to leverage for therapeutic interchange. Prescribers may, however, be able to authorize therapeutic interchange on a patient-by-patient basis in community pharmacy settings by allowing pharmacists to leverage the formulary of the patient's health plan. This approach can replicate the safeguards established within an institutional setting while saving money and reducing bureaucratic hassles. To date, 3 states have adopted this practice into law. The purpose of this article is to explore the legislative and regulatory considerations in authorizing therapeutic interchange in community pharmacy settings.

\section{Considerations for Policy Development}

Several organizations have published position statements outlining under what circumstances therapeutic interchange should take place. ${ }^{11-16}$ These organizations represent patient and disease advocacy groups and pharmacy, physician, and managed care organizations. Although each position statement was published separately, a consensus appears to have been independently reached among multiple organizations around the following points:

1. Therapeutic interchange should only be used for medications expected to provide a substantially similar benefit to those desired from the originally prescribed medication. ${ }^{11-15}$

2. Therapeutic interchange is appropriate where there is some type of evidence-based formulary, developed with the input of interdisciplinary health professions, to help facilitate decision making. ${ }^{11,13-15}$

3. Interchange should be considered in light of therapeutic benefit foremost, followed by cost considerations. ${ }^{11,12,15}$ 


\section{TABLE 1 Summary of Current U.S. Legislation}

\begin{tabular}{|c|c|c|c|}
\hline Parameter & Idaho $^{21}$ & Kentucky $^{19}$ & Arkansas $^{20}$ \\
\hline $\begin{array}{l}\text { Does the prescriber } \\
\text { have to opt-in? }\end{array}$ & Yes & Yes & Yes \\
\hline $\begin{array}{l}\text { Does the substitution } \\
\text { have to be in compli- } \\
\text { ance with the health } \\
\text { plan formulary? }\end{array}$ & $\begin{array}{l}\text { Yes, unless in } \\
\text { the case of a } \\
\text { patient without } \\
\text { health insur- } \\
\text { ance, in which } \\
\text { case the intent } \\
\text { is to lower the } \\
\text { cost to the } \\
\text { patient while } \\
\text { maintaining } \\
\text { safety }\end{array}$ & Yes & $\begin{array}{l}\text { No, the phar- } \\
\text { macist may } \\
\text { substitute a } \\
\text { drug that is at } \\
\text { a lower cost to } \\
\text { the patient }\end{array}$ \\
\hline $\begin{array}{l}\text { Does the patient have } \\
\text { to opt-in? }\end{array}$ & Yes & No & Yes \\
\hline $\begin{array}{l}\text { If a substitution is } \\
\text { made, must the } \\
\text { original prescriber } \\
\text { be notified? }\end{array}$ & Yes & Yes & Yes \\
\hline $\begin{array}{l}\text { Are any drugs } \\
\text { explicitly excluded? }\end{array}$ & $\begin{array}{l}\text { Yes, biologics } \\
\text { and narrow } \\
\text { therapeutic } \\
\text { index drugs }\end{array}$ & No & No \\
\hline
\end{tabular}

4. Patients should be notified of and agree to any change before dispensing the medication. ${ }^{11,15}$

5. Pharmacies should retain records of any interchange performed..$^{12,13}$

6. Physicians should be notified of interchange within a reasonable time period after the change occurs. ${ }^{11,13}$

7. There should be some mechanism in place to exclude patients and medications from interchange when clinically inappropriate. ${ }^{11,12,15}$

Concerns regarding therapeutic interchange generally focus on certain circumstances or practices, not blanket opposition. Perhaps the most widely expressed concern regards patient safety as it relates to narrow therapeutic index drugs, particularly for psychoactive medications, which can have different actions and effects even in the same therapeutic class. ${ }^{15,16} \mathrm{In}$ addition, some have noted that pharmacists should have a conversation with the physician about which medication they will dispense before dispensing it. ${ }^{17}$ Finally, some have expressed concerns that physicians may be confused about how therapeutic interchange differs from brand-generic substitution and may not be sure what they are opting-in to. ${ }^{17}$

\section{Current Legal Authority in the United States}

Therapeutic interchange could occur in the 17 states that allow population-specific collaborative practice agreements (CPAs), although there are practical impediments to doing so. ${ }^{18}$ There are currently only 3 states with legislation authorizing therapeutic interchange in community pharmacy settings outside of a CPA: Arkansas, Kentucky, and Idaho. ${ }^{19-21}$ A summary of the core elements of the laws in each of these states is outlined in Table 1.
In 2003, Kentucky was the first state to pass a law authorizing this practice. Arkansas followed suit in 2015, and Idaho's legislation took effect on July 1, 2018. Arkansas and Idaho have adopted an identical definition of "therapeutic class" to guide interchange: "A group of similar drug products that have the same or similar mechanisms of action and are used to treat a specific condition."

All 3 states require that the physician opt-in to the interchange; thus, the decision to allow interchange is at the discretion of the original prescriber on a patient-by-patient basis. In Kentucky, for example, the prescriber must write "formulary compliance approval" on the prescription or check a box to that effect, whereas in Arkansas and Idaho, the physician must write "therapeutic substitution allowed" or make "a similar designation."

Idaho and Kentucky require that the substitution be in compliance with the patient's health plan formulary, such as changing from a nonpreferred drug to a preferred drug. Arkansas states that the substitution must be to a drug "that is at a lower cost to the patient." Idaho adapts this lower cost language for patients who do not have health plan coverage, allowing switches to a lower-cost drug in these instances. Kentucky is silent on how to handle interchange for patients without an insurer.

All 3 states require notification back to the original prescriber of any interchange in order to ensure a complete and accurate medication record. Arkansas and Kentucky require this notification within 24 business hours. Idaho requires notification within 5 days, which synchronizes this notification with that required for drugs that Idaho pharmacists can independently prescribe. ${ }^{22}$ Only Idaho explicitly prohibits interchange for narrow therapeutic index drugs and biological products, since a separate state law governs substitution of biosimilars.

\section{Review of Canadian Pharmacy Law}

Currently, 7 of 13 Canadian provinces and territories allow therapeutic interchange by law (Nova Scotia, Prince Edward Island, Newfoundland, Saskatchewan, Alberta, British Columbia, and New Brunswick). ${ }^{23}$ These laws vary by province, but on the least restrictive end, therapeutic interchange is permissible even without physician opt-in; therefore, interchange can be the default position for the pharmacist. ${ }^{24}$ Similarly, in some provinces, notification is only provided to the original prescriber when the change is deemed "clinically significant." The prescriber retains the ability to opt-out of the interchange by indicating "do not adapt" or a similar designation on the prescription.

\section{Discussion}

Getting therapeutic interchange legislation passed can be a difficult prospect, as indicated by only 3 states having such laws 


\begin{tabular}{l|l}
\hline \multicolumn{1}{c}{ TABLE 2 } & \multicolumn{1}{c}{$\begin{array}{l}\text { Opportunities to Address Concerns } \\
\text { Regarding Therapeutic Interchange }\end{array}$} \\
\hline Concern & \multicolumn{1}{c}{ Potential Policy Response } \\
\hline $\begin{array}{l}\text { Narrow therapeutic } \\
\text { index drugs can pose } \\
\text { patient safety issues, as } \\
\text { a small change in blood } \\
\text { concentration can lead } \\
\text { to a major difference in } \\
\text { patient response. }\end{array}$ & $\begin{array}{l}\text { Policy can expressly prohibit interchange for nar- } \\
\text { row therapeutic index drugs. Idaho law states: } \\
\text { therapeutic index drugs." Idaho law further } \\
\text { defined narrow therapeutic index drugs as "a } \\
\text { drug where a small difference in dose or blood } \\
\text { concentration may lead to serious therapeutic } \\
\text { failures or adverse drug reactions." }\end{array}$ \\
\hline $\begin{array}{l}\text { Pharmacists should have } \\
\text { a conversation with the } \\
\text { physician about which } \\
\text { medication they will dis- } \\
\text { pense before dispensing it. }\end{array}$ & $\begin{array}{l}\text { Policy can require a physician to opt-in on the } \\
\text { original prescription. This proactive prescriber } \\
\text { opt-in, which occurs before dispensing, retains } \\
\text { prescriber autonomy but removes the hassle } \\
\text { of the pharmacist having to contact the pre- } \\
\text { scriber for common sense interchanges when } \\
\text { the patient's health plan has a different preferred } \\
\text { drug in the same therapeutic class. }\end{array}$ \\
\hline $\begin{array}{l}\text { Physicians may be con- } \\
\text { fused about how thera- } \\
\text { peutic interchange dif- } \\
\text { fers from brand-generic } \\
\text { substitution and may not } \\
\text { be sure what they are } \\
\text { opting-in to. }\end{array}$ & $\begin{array}{l}\text { Brand-generic substitution has become a default } \\
\text { that prescribers can opt-out of. In 2016, nearly } \\
\text { 3.9 billion generic prescriptions were dispensed } \\
\text { in the United States. 27 Requiring a prescriber to } \\
\text { opt-in to therapeutic interchange creates a suit- } \\
\text { able distinction between the 2 concepts. }\end{array}$ \\
\hline
\end{tabular}

that enable the practice in community pharmacy settings. The core elements of these existing state laws closely align with the tenants put forth in the position statements issued by patient advocacy groups and pharmacy, physician, and managed care organizations.

Legislation can be and has been structured to address core issues. First, leveraging a health plan's formulary as the basis for interchange within a therapeutic class can appropriately balance therapeutic benefits with cost considerations. This leveraging can further eliminate the perception of conflict of interest associated with pharmacists switching medications. Second, physician opt-in allows patient-by-patient decisions on therapeutic interchange. Simply put, if a physician wants a patient to be on a specific drug, he or she simply does not have to indicate "therapeutic substitution allowed" on the prescription. Third, laws can respect the tenets of informed choice by requiring the patient's agreement to any change. In Idaho, for example, the law requires the pharmacist to "clearly inform" the patient of any differences in the drug products and specify that "the patient may refuse the substitution." 21

Of note, several Canadian provinces have laws that are more progressive than those in the United States, whereby the default is to allow interchange, and the physician has to opt-out if he or she does not want a product to be changed. Even with this practice, Canada has a safe track record. In the first year that therapeutic interchange was allowed in British Columbia, pharmacists performed 3,713 substitutions. ${ }^{25}$ The most commonly substituted medications included rabeprazole $(n=1,098)$, beclomethasone $(n=211)$, and naproxen $(n=161)$. No safety issues have been reported. . $^{25,26}$

The most significant concern expressed over therapeutic interchange concerns narrow therapeutic index drugs. Legislation can explicitly exclude these from interchange, as Idaho did in law. Even without an express carve out, Arkansas and Kentucky practically exempt these drug categories, since it is unlikely that prescribers and patients would each separately opt-in to such a substitution, and equally unlikely that a pharmacist would offer. Table 2 includes a list of policy considerations that may address historical concerns over therapeutic interchange.

\section{Conclusions}

Therapeutic interchange allows pharmacists to use their medication expertise, to save valuable time, and enhance patient care while reducing health care costs. In doing so, patient safety has not been shown to be compromised. While theoretical concerns have been raised, they have been safely and effectively addressed in Arkansas, Idaho, and Kentucky, and no known reports of patient harm have resulted in these states (Arkansas and Kentucky have had more than 10 years of combined practice experience). Thus, more jurisdictions may consider appropriately structured therapeutic interchange laws (e.g., prescriber opt-in, limited to drugs in the same therapeutic class, leverage the health plan formulary, and require prescriber notification) in the years ahead.

\section{Authors}

THOMAS VANDERHOLM, PharmD, Washington State University, Spokane; DONALD KLEPSER, PhD, MBA, College of Pharmacy, University of Nebraska Medical Center, Omaha; and ALEX J. ADAMS, PharmD, MPH, Idaho State Board of Pharmacy, Boise.

AUTHOR CORRESPONDENCE: Alex J. Adams, PharmD, MPH, Executive Director, Idaho State Board of Pharmacy, 1199 W. Shoreline Ln., Ste. 303, Boise, ID 83702. Tel.: 419.708.5186; E-mail: AlexAdamsRPh@gmail.com.

\section{DISCLOSURES}

No funding supported the writing of this article. The authors have nothing to disclose.

\section{REFERENCES}

1. Kaczik A. Drug prices expected to rise nearly $8 \%$ next year. Modern Healthcare. July 25, 2017. Available from: http://www.modernhealthcare. com/article/20170725/NEWS/170729943. Accessed September 24, 2018.

2. Adams AJ. Prescription adaptation services: a regulatory and practice perspective. Ann Pharmacother. 2018;52(7):700-03. 
3. Look KA, Mott DA, Leedham RK, Kreling DH, Hermansen-Kobulnicky CJ. Pharmacy participation and claim characteristics in the Wisconsin Medicaid Pharmaceutical Care Program from 1996 to 2007. J Manag Care Pharm. 2012;18(2):116-28. Available at: https://www.jmcp.org/doi/10.18553/ jmcp.2012.18.2.116.

4. Look KA, Mott DA, Kreling DH, Peterson EJ, Staresinic AG. Economic impact of pharmacist-reimbursed drug therapy modification. J Am Pharm Assoc (2003). 2011;51(1):58-64.

5. Johansen ME, Richardson C. Estimation of potential savings through therapeutic substitution. JAMA Intern Med. 2016;176(6):769-75.

6. Pedersen CA, Schneider PJ, Scheckelhoff DJ. ASHP national survey of pharmacy practice in hospital settings: prescribing and transcribing-2016. Am J Health Syst Pharm. 2017;74(17):1336-52.

7. Schachtner JM, Guharoy R, Medicis JJ, Newman N, Speizer R. Prevalence and cost savings of therapeutic interchange among U.S. hospitals. Am J Health Syst Pharm. 2002;59(6):529-33

8. Brushwood D. Legal issues surrounding therapeutic interchange in institutional settings: an update. Formulary. 2001;36:796-804.

9. Carroll NV. Impact of generic and therapeutic interchange incentives on community pharmacy. Am Pharm. 1995;35(7):27-34.

10. Carroll NV. Therapeutic interchange in community pharmacies in Virginia. Am J Health Syst Pharm. 2000;57(9):882-86.

11. The American Heart Association, The American Stroke Association. American Heart Association/American Stroke Association Statement on Drug Formularies. 2015. Available at: https://www.heart.org/idc/groups/ heart-public/@wcm/@adv/documents/downloadable/ucm_435977.pdf. Accessed September 24, 2018.

12. National Association of Boards of Pharmacy. Report of the Task Force on Therapeutic Interchange. 1993. Available at: https://nabp.pharmacy/ wp-content/uploads/2016/07/TF_Therapetic_Interchange.pdf. Accessed September 24, 2018.

13. Gray T, Bertch K, Galt K, et al. Guidelines for therapeutic interchange-2004. Pharmacotherapy. 2005;25(11):1666-80. Available at: https:// www.accp.com/docs/positions/guidelines/Pharm2511_ACCP-TherapIntchg. pdf. Accessed September 24, 2018.

14. Academy of Managed Care Pharmacy. Therapeutic interchange. 2012. Available at: http://www.amcp.org/WorkArea/DownloadAsset. aspx?id=18745. Accessed September 24, 2018.

15. Holmes DR, Becker JA, Granger CB, et al. ACCF/AHA 2011 Health Policy Statement on Therapeutic Interchange and Substitution. Circulation. 2011;124(11):1290-310. Available at: https://www.ahajournals.org/doi/ full/10.1161/CIR.0b013e31822d97d5. Accessed September 24, 2018.
16. National Consumers League. Common therapeutic drug substitutions. January 2009. Available at: http://www.nclnet.org/common_therapeutic_ drug_substitutions. Accessed September 24, 2018.

17. Moran M. Assembly responds to Arkansas law on "therapeutic substitution." Psychiatric News. August 5, 2016. Available at: https://psychnews. psychiatryonline.org/doi/full/10.1176/appi.pn.2016.PP8a2. Accessed September 24, 2018.

18. Adams AJ, Weaver KK. The continuum of pharmacist prescriptive authority. Ann Pharmacother. 2016;50(9)778-84.

19. Kentucky State Legislature. 201 KAR 2:280. Prescription dispensing for formulary compliance. 2003. Available at: http://www.lrc.ky.gov/ kar/201/002/280.pdf. Accessed October 8, 2018.

20. Arkansas State Legislature. Regulation 7-drug products/prescriptions. 07-00: General regulations regarding drugs/prescriptions. 2014. Available at: www.pharmacyboard.arkansas.gov/Websites/pharmacy/images/rules/ Regulation7.pdf. Accessed September 24, 2018.

21. Idaho State Legislature. House Bill 339. 2018. Available at: https://legislature.idaho.gov/wp-content/uploads/sessioninfo/2018/legislation/H0339. pdf. Accessed September 24, 2018

22. Idaho State Board of Pharmacy. Rule Docket 27-0104-1701. Rules Governing Pharmacist Prescriptive Authority. Available at: https://adminrules.idaho.gov/rules/current/27/270104.pdf. Accessed October 8, 2018.

23. Canadian Pharmacists Association. Pharmacists' scope of practice in Canada. December 2016. Available at: https://www.pharmacists.ca/cpha-ca/ assets/File/cpha-on-the-issues/ScopeofPracticeinCanada_DEC2016.pdf. Accessed September 24, 2018.

24. New Brunswick College of Pharmacists. Regulations of the New Brunswick College of Pharmacists. 2018. Available at: https://nbcp.inltouch. org/document/1733/2015\%2007\%2023\%20REGS\%20bilingual.pdf. Accessed October 5, 2018.

25. Marra C, Lynd L, Grinrod, et al. An overview of pharmacy adaptation services in British Columbia. Available at: https://www2.gov.bc.ca/assets/ gov/health/health-drug-coverage/pharmacare/coreadaptationoverview.pdf. Accessed September 24, 2018.

26. Marra CA, Lynd LD, Grinrod KA, et al. Evaluating the labour costs associated with pharmacy adaptation services in British Columbia. Can Pharm J (Ott). 2012;145(2):78-82

27. Association for Accessible Medicines. 2017 generic drug access and savings in the U.S. Report. Available at: https://accessiblemeds.org/resources/ blog/2017-generic-drug-access-and-savings-us-report. Accessed September 24, 2018.

28. Picchi A. Drug ads: $\$ 5.2$ billion annually-and rising. CBS News MoneyWatch. March 11, 2016. Available from: https://www.cbsnews.com/ news/drug-ads-5-2-billion-annually-and-rising/. Accessed September 24, 2018 